\title{
Reproductive characteristics of wild boar males (Sus scrofa) under different environmental conditions
}

\author{
Jakub Drimaj ${ }^{1}$, Jiří Kamler ${ }^{1}$, Martin Hošek ${ }^{2}$, Jaroslav Zeman ${ }^{1}$, \\ Radim Plhal $^{1}$, Ondřej Mikulka ${ }^{1}$, Tomáš Kudláček ${ }^{1}$
}

Mendel University in Brno, ${ }^{1}$ Faculty of Forestry and Wood Technology, Department of Forest Protection and Wildlife Management, ${ }^{2}$ Faculty of AgriSciences, Department of Animal Breeding, Brno, Czech Republic

\author{
Received March 13, 2019
}

Accepted October 29, 2019

\begin{abstract}
The wild boar population has been on a permanent increase over the last decades, causing conflicts with the requirements of modern human society. Existing effort to stabilize wild boar numbers generally fails with one of the causes being the high reproductive potential of wild boar. The aim of this study was to assess the onset of sexual maturity in wild boar males with regard to age, physical frame and environmental conditions on the basis of testicle development and sperm production. This study assessed the dimensions of gonads and the occurrence of sperm in boars caught during common hunts. Environmental conditions were found as an important factor for growth and sexual maturity of wild boar males. The body weight was a more important factor for sperm production than the age of young wild boar males. The weight threshold for sperm production in the testes was $29 \mathrm{~kg}$ of live weight, which corresponds to 6 months of age on average. This study has proven that environmental conditions are a significant factor affecting the physical development of male wild boars, more specifically the growth rate of their body frames and the onset of sexual maturity. In a better quality environment boars grow faster and enter puberty at an earlier age. Poor food supply and/or high hunting pressure result in slower body and testicular growth, as well as the production of sperm at a later age (approx. 2-3 months later).
\end{abstract}

Testicles, gonads, mating season, sperm, feeding, body weight

The wild boar (Sus scrofa), is currently one of the most widely discussed large mammals of Europe and certain other areas of the world. The main reason for the interest in wild boar is the steady and rapid increase in their populations over the last decades (Massei et al. 2015) and the resulting conflicts with the requirements of modern human society. These conflicts are reflected e.g. in damage to agricultural crops (Herrero et al. 2006), negative effects on environmental diversity (Massei and Genov 2004), and the spread of parasites and diseases, e.g. the African swine fever (Sánchez-Vizcaíno et al. 2013) or hepatitis E virus (Carpentier et al. 2012).

Consequently, much attention is also paid to the factors contributing to the high reproduction rates of wild boar (Apollonio et al. 2010). Important factors include the disproportionate social structure of the population (there are considerably more female than male boars older than 2 years), easy access to a substantial amount of quality food throughout the year, favourable climate, and also a shift in the reproductive strategy of boars, which have begun to reproduce en masse in the first year of their lives $(\mathrm{Oja}$ et al. 2014).

The wild boar reproduction is seasonal and regulated by photoperiodicity (Keuling et al. 2018), but piglets can be born at virtually any time (Orłowska et al. 2013). Nevertheless, it can be stated that most females reproduce during the primary reproductive season from November to March (Mauget 1972). The social structure of wild boar populations over the course of the year is a dynamic system. Family groups formed by old sows, their adult

Address for correspondence: 
daughters and young piglets of both sexes constitute its foundation. Adult males, which live by themselves, join the groups for reproduction seasons (Truvé and Lemel 2003). Young males leave their family packs when they are approximately one year old and form their own packs outside of the family groups. The mating system is commonly described as polygynous (Fernández-Llario et al. 1999), some authors, however, describe it as polygynandrous or promiscuous (Pérez-González et al. 2014) in view of evidence of multiple paternity within litters (Delgado-Acevedo et al. 2011).

Females begin reproducing when they are approximately 7 months old and weigh around $20 \mathrm{~kg}$, with these parameters depending largely on the availability of food (e.g. Gethöffer et al. 2007). It is not clear to what extent these young and morphologically immature

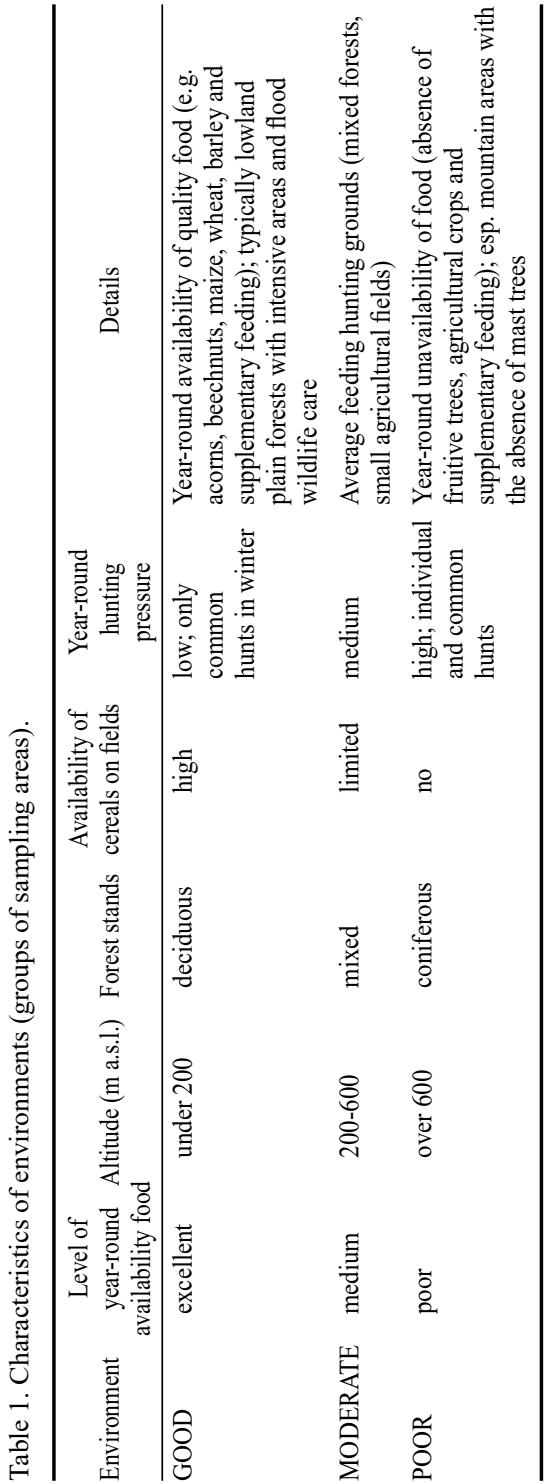
females are capable of mating with strong adult boars, and how reproductively mature similarly aged males are.

Reproduction ability is determined by a number of factors influencing the animal in the provided environment; it is directly tied to its physical development. While females need to be sexually mature as well as be adequately physically developed and have sufficient fat reserves in order to take part in active reproduction, the reproductive ability of a young male is determined mainly by the development of his gonads and their capacity for producing viable sperm. In the last decades, young females have begun to reproduce en masse, it is therefore likely that environmental conditions have the same effect on males, which should be capable of fertilizing females of the same age (Murta et al. 2013).

The aim of this study was to assess the onset of puberty and sexual maturity in wild boar males with regard to body size, age, and environmental conditions on the basis of testicle development and sperm production. We hypothesized that: 1) young boar males living in high-quality environment grow faster and reach their sexual maturity earlier, and 2) the sexual maturity of wild boar males depends more on their body size than their age.

\section{Materials and Methods}

The sexual maturity of males was assessed by analysing the reproductive organs of animals harvested during collective hunts from November 2014 to January 2015. Samples were collected from 21 unfenced areas that were distributed unevenly across the Czech Republic. Sampling areas were divided into three groups according to the quality and management of the environment during the whole year (Table 1, Fig. 1).

Males were weighed before (live weight) and after evisceration, their age was determined from tooth eruption and wear (Briedermann 1965; Matschke 1967; Boitani and Mattei 1992), and body length was measured to the 


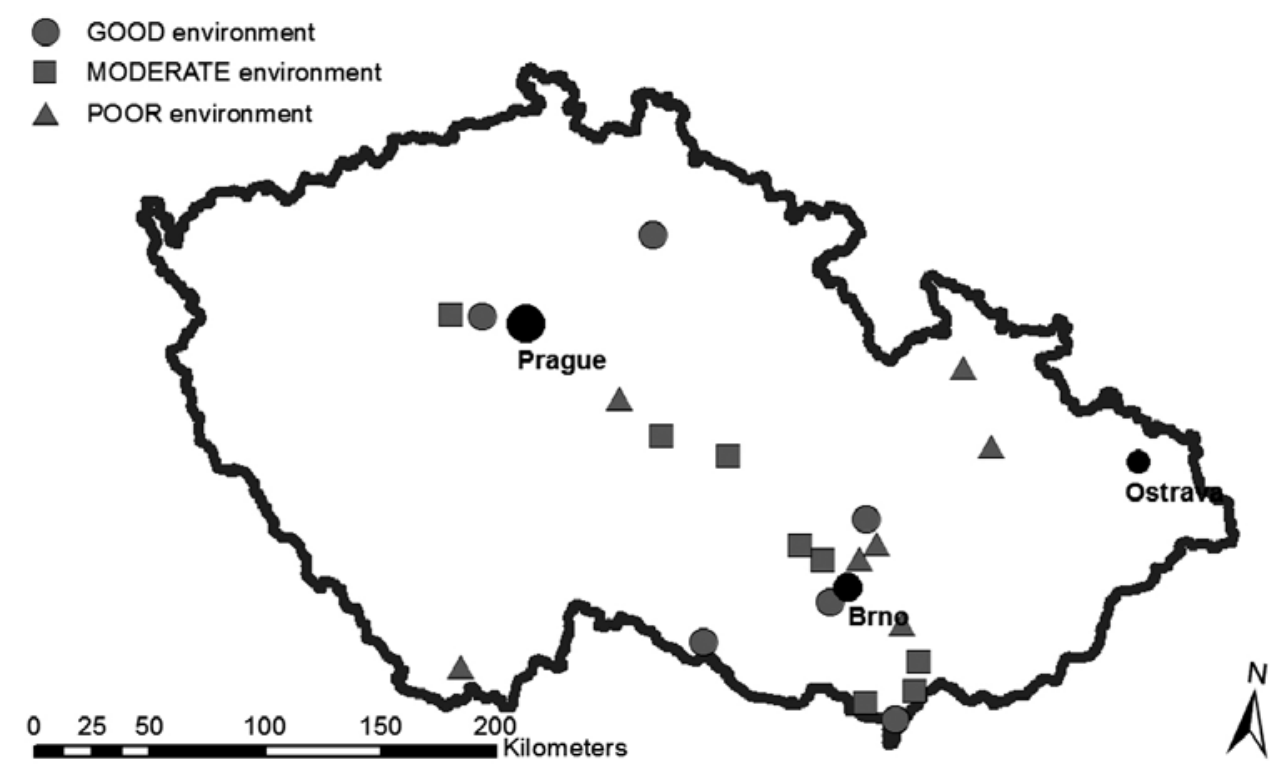

Fig. 1. Localization of sampling areas in the Czech Republic according to the quality of environmental groups

nearest millimetres (distance of snout-tail). In order to minimize errors, all determining and measuring was performed by the same person. After that, the testes with their epididymides were removed and frozen until the time of the analysis. The excisional incisions were made by transecting the ejaculatory duct, the vas deferens, $10 \mathrm{~cm}$ from the epididymis.

After defrosting at room temperature $\left(20{ }^{\circ} \mathrm{C}\right)$, both testes with epididymides were stripped of excess tissue and the length and width of the each testis and its epididymis was determined to the nearest $0.01 \mathrm{~mm}$ (selected parameters from Věžník et al. 2004) and the weight of each testis with and without the epididymis was determined to the nearest $0.01 \mathrm{~g}$. Testicular volume was calculated using the following formula (Bekaert et al. 2012): Volume $=$ length $\times$ width $^{2} \times(\pi / 6)$. The gonadosomatic index $(\mathrm{GSI})$ was calculated using the following formula (Barber and Blake 1991):

GSI $=$ testis weight $/$ body weight $\times 100$.

The testes were cut in 3 places - the head, body, and tail of each epididymis - and the imprinting preparations were placed on microscope slides. Subsequently, the presence or absence of sperm was determined under a microscope at a $\times 300$ magnification.

All biological material was handled in accordance with the relevant veterinary and health directives and was disposed of adequately.

All analyses were performed in the R software (R Development Core Team 2008):

1. Modelling individual relationships between body parameters and environment quality: Individual relationships were modelled using generalized linear models and log-linear regression. Multiple comparisons were carried out using a likelihood-ratio test.

2. Model of the relationship between GSI and body weight: Various models were compared in performance terms by means of nested Monte Carlo cross-validation with 10,000 iterations. Tested models included various penalized polynomial regressions (LASSO, Ridge and Elastic Net Regularization) and 21 different sigmoid functions implemented in the drc package (Ritz et al. 2015) - these were included on the basis of visual assessment of the data. Mean cross-validated error served as a criterion for the final model selection.

3. Complex models: The variable selection problem was addressed by the elastic net algorithm implemented in the glmnet package (Friedman et al. 2010), where the regularization parameter lambda was determined through cross-validation. Hyperparameters optimization and model selection was performed via nested Monte Carlo cross-validation with 10,000 iterations. The final model was selected based on the mean cross-validated error. In the case of modelling the continuous response variable - the testicle weight - the forecast accuracy was expressed by the mean absolute percentage error (MAPE). In the case of logistic regression - modelling the probability of sperm presence - the criterion for model selection was the misclassification rate. 


\section{Results}

Altogether, the reproductive organs of 145 males from 21 areas divided into three environments were analysed (Table 1, Fig. 1). As mostly piglets in the first year of their life $(81 \%)$ were analysed, the age structure of the males was unbalanced, but the number of equally old individuals (in the key age of 6-11 months) was balanced across the environmental quality. Adult males accounted for $11 \%$ and half of these were males aged 2-3 years. There were only 7 fully adult males older than 3 years (Table 2). The body weight ranged from 11 to $60 \mathrm{~kg}$ in piglets, from 62 to $102 \mathrm{~kg}$ in young adults, and from 84 to $145 \mathrm{~kg}$ in adults. In all dead boars, this parameter seemed to be closely correlated with age $(\mathrm{r}=0.86 ; P<0.001)$, with the biggest correlation apparent in piglets $(\mathrm{r}=0.67$; $P<0.001)$. The proportion of internal organ weight to the weight of a live boar ranged from $1 / 4$ in piglets to $1 / 6$ in adults $(\mathrm{r}=-0.49 ; P<0.001)$, which is related to the development of musculature and skeleton during the process of morphological and physiological maturation. Table 3 shows an overview of the measured physical parameters.

Table 2. Numbers and basic characteristics of wild boar males.

\begin{tabular}{lcccccr}
\hline Class of age & Age (months) & Anim (n) & $\begin{array}{c}\text { Mean body } \\
\text { weight } \\
(\mathrm{kg})\end{array}$ & $\begin{array}{c}\text { Proportion of } \\
\text { viscera } \\
(\% \text { body weight })\end{array}$ & $\begin{array}{c}\text { GSI } \\
(\%)\end{array}$ & $\begin{array}{c}\text { Individuals } \\
\text { with sperm } \\
(\%)\end{array}$ \\
\hline Piglets & $1-12$ & 118 & $37.3 \pm 10.1$ & $25.5 \pm 5.2$ & $0.09 \pm 0.08$ & 66.9 \\
Yearlings & $13-24$ & 11 & $79.0 \pm 13.1$ & $20.8 \pm 3.0$ & $0.36 \pm 0.07$ & 100.0 \\
Adults & $24<$ & 16 & $105.8 \pm 16.8$ & $17.2 \pm 3.9$ & $0.39 \pm 0.07$ & 100.0 \\
\hline
\end{tabular}

Anim - animals; GSI - gonadosomatic index

Table 3. Mean body weight and length of wild boar males.

\begin{tabular}{lrcc}
\hline $\begin{array}{l}\text { Age } \\
\text { (months) }\end{array}$ & $(\mathrm{n})$ & $\begin{array}{c}\text { Body weight } \\
(\mathrm{kg})\end{array}$ & $\begin{array}{c}\text { Body length } \\
(\mathrm{mm})\end{array}$ \\
\hline 2 & 1 & 11.0 & 720.0 \\
3 & 1 & 14.0 & 790.0 \\
5 & 6 & $25.7 \pm 4.3$ & $925.3 \pm 38.9$ \\
6 & 33 & $32.5 \pm 7.3$ & $990.6 \pm 72.3$ \\
7 & 18 & $33.8 \pm 8.9$ & $997.1 \pm 133.1$ \\
8 & 21 & $38.3 \pm 5.1$ & $1086.7 \pm 72.2$ \\
9 & 21 & $43.5 \pm 8.2$ & $1124.7 \pm 65.2$ \\
10 & 12 & $48.1 \pm 8.6$ & $1128.4 \pm 81.9$ \\
11 & 3 & $51.5 \pm 5.6$ & $1175.0 \pm 25.5$ \\
12 & 2 & $55.0 \pm 0.8$ & $1176.7 \pm 70.4$ \\
$13-24$ & 11 & $79.0 \pm 13.7$ & $1372.0 \pm 84.9$ \\
$24<$ & 16 & $105.8 \pm 17.3$ & $1428.4 \pm 121.5$ \\
\hline
\end{tabular}

Body length depended the most on body weight and less on age. There was a strong relationship between body length and body weight: $\mathrm{r}=0.88 ; P<0.001$ (all cases) and $\mathrm{r}=0.81 ; P<0.001$ (piglets). A significant relationship was also found between body length and age: $\mathrm{r}=0.75 ; P<0.001$ (all cases) and $\mathrm{r}=0.67 ; P<0.001$ (piglets).

\section{Basic characteristics of reproductive organs}

The total volume of gonads (both testes) ranged from $41.4 \mathrm{~mm}^{3}$ in piglets to $598.7 \mathrm{~mm}^{3}$ in adult males. The highest value was measured in a male aged 6 years; the volume of testes was $903.6 \mathrm{~mm}^{3}$ with the weight of one testicle a little over $250 \mathrm{~g}(0.5 \mathrm{~kg}$ including epididymis). The determined parameters of the gonads are detailed in Table 4.

Close correlations were discovered between testicular weight and body weight $(\mathrm{r}=$ 0.94; $P<0.001)$ and also the mean testicle length and body length $(\mathrm{r}=0.88 ; P<0.001)$. Differences between the left and right testicle in volume, weight, and dimensions were not observed $(P<0.001)$. The measured physical parameters and dimensions of the testes correlated at the values of $\mathrm{r}=0.7-0.8(P<0.001)$. On average, the ratio of gonad weight to body weight (GSI) was $0.14 \pm 0.13 \%$ (Fig. 2). The relationship between GSI and body weight was best explained by the following Weibull model: 
Table 4. Mean testicular parameters of wild boar males.

\begin{tabular}{cccccccc}
\hline $\begin{array}{c}\text { Age } \\
(\text { months })\end{array}$ & $\begin{array}{c}\text { Anim } \\
(\mathrm{n})\end{array}$ & $\begin{array}{c}\text { Anim } \\
\text { with }(\%)\end{array}$ & $\begin{array}{c}\text { Testicle } \\
\text { length }(\mathrm{mm})\end{array}$ & $\begin{array}{c}\text { Testicle } \\
\text { width }(\mathrm{mm})\end{array}$ & $\begin{array}{c}\text { Testicle } \\
\text { weight }(\mathrm{g})\end{array}$ & $\begin{array}{c}\text { Epididymis } \\
\text { weight }(\mathrm{g})\end{array}$ & $\begin{array}{c}\text { Testicle } \\
\text { volume }\left(\mathrm{cm}^{3}\right)\end{array}$ \\
\hline $2-5$ & 8 & 0.0 & $29.5 \pm 4.2$ & $16.3 \pm 2.1$ & $5.1 \pm 1.8$ & $2.7 \pm 0.7$ & $4.2 \pm 1.5$ \\
6 & 33 & 42.4 & $32.3 \pm 4.6$ & $19.6 \pm 3.2$ & $8.3 \pm 7.0$ & $4.1 \pm 1.7$ & $6.9 \pm 3.5$ \\
7 & 18 & 41.2 & $34.5 \pm 10.4$ & $21.0 \pm 6.2$ & $9.7 \pm 8.4$ & $5.7 \pm 6.7$ & $10.2 \pm 13.1$ \\
8 & 21 & 95.2 & $38.4 \pm 9.7$ & $23.5 \pm 6.4$ & $14.5 \pm 10.9$ & $5.6 \pm 3.8$ & $13.4 \pm 11.2$ \\
9 & 21 & 95.5 & $52.4 \pm 14.4$ & $33.4 \pm 9.1$ & $34.2 \pm 22.2$ & $14.0 \pm 9.6$ & $37.1 \pm 26.9$ \\
$10-11$ & 15 & 100.0 & $57.0 \pm 17.1$ & $36.1 \pm 12.3$ & $44.4 \pm 28.9$ & $16.3 \pm 11.5$ & $49.9 \pm 40.0$ \\
$12-16$ & 4 & 100.0 & $73.5 \pm 17.2$ & $48.9 \pm 15.1$ & $89.5 \pm 61.4$ & $33.0 \pm 18.2$ & $108.7 \pm 75.2$ \\
$17-24$ & 9 & 100.0 & $92.0 \pm 13.0$ & $61.1 \pm 8.5$ & $141.6 \pm 38.7$ & $68.8 \pm 28.8$ & $187.2 \pm 71.4$ \\
$25 \leq$ & 16 & 100.0 & $109.3 \pm 9.2$ & $71.8 \pm 6.8$ & $208.6 \pm 52.3$ & $122.7 \pm 42.0$ & $299.4 \pm 82.0$ \\
\hline
\end{tabular}

Anim - animals

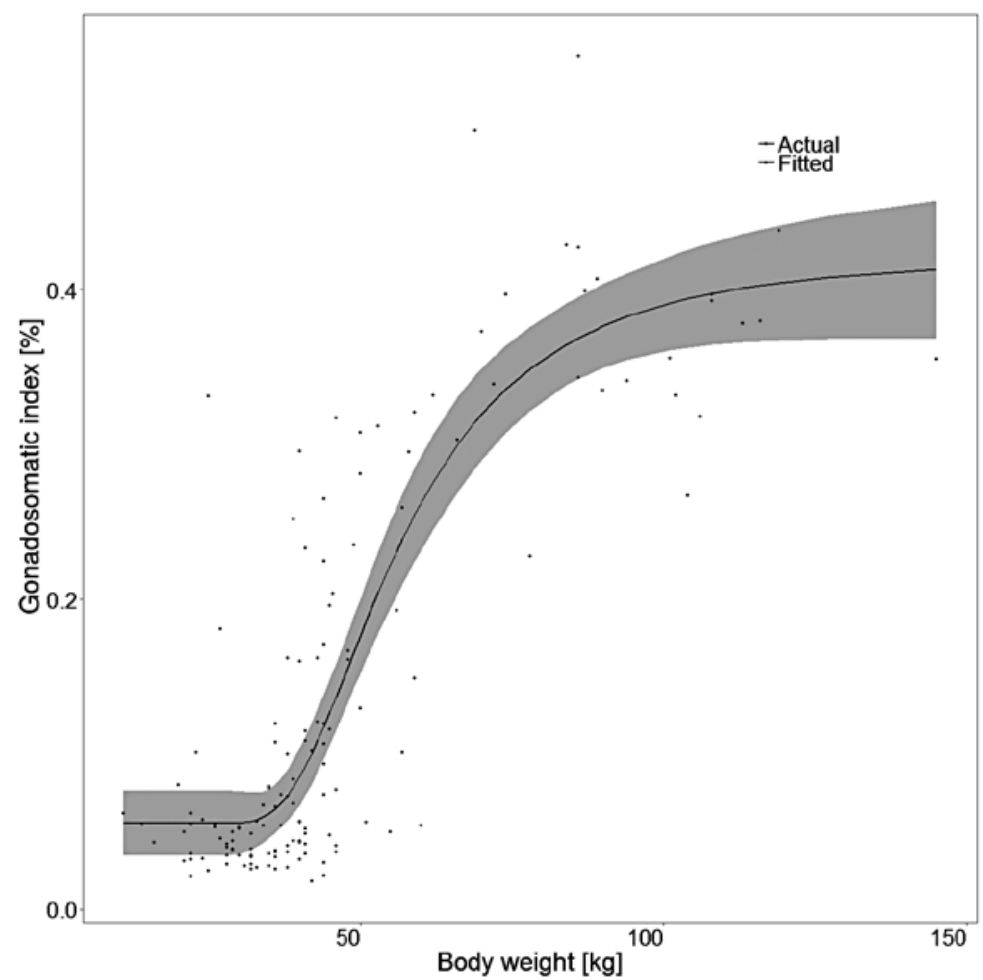

Fig. 2. Relationship between body weight and gonadosomatic index in wild boar $\left(\mathrm{r}^{2}=0.66 ; P<0.001\right)$

GSI (body_weight) $=0.056 \mathrm{c}+(0.421 \mathrm{~d}-0.056 \mathrm{c}) \exp (-\exp (3.637 \mathrm{~b}(\log (\mathrm{x})$ $+\log (51.442 \mathrm{e}) \overline{)}))$

The formula implies that the fastest growth of GSI occurs for the body weight of $51.44 \mathrm{~kg}$, which corresponds to approximately 11 months of age. 
The effect of environmental quality on physical development and reproductive organs

Due to insufficient data for adult boars, environmental influence was only evaluated in piglets. Environmental quality significantly affected the growth of piglets in the first year of their lives and the development of their reproductive organs. The GSI, body weight and body length (Fig. 3) of males living in POOR environment were significantly lower compared with males living in GOOD and MODERATE environments $(P<0.001)$. There was also a significant difference in body weight between boars living in GOOD and MODERATE environments $(P<0.001)$.

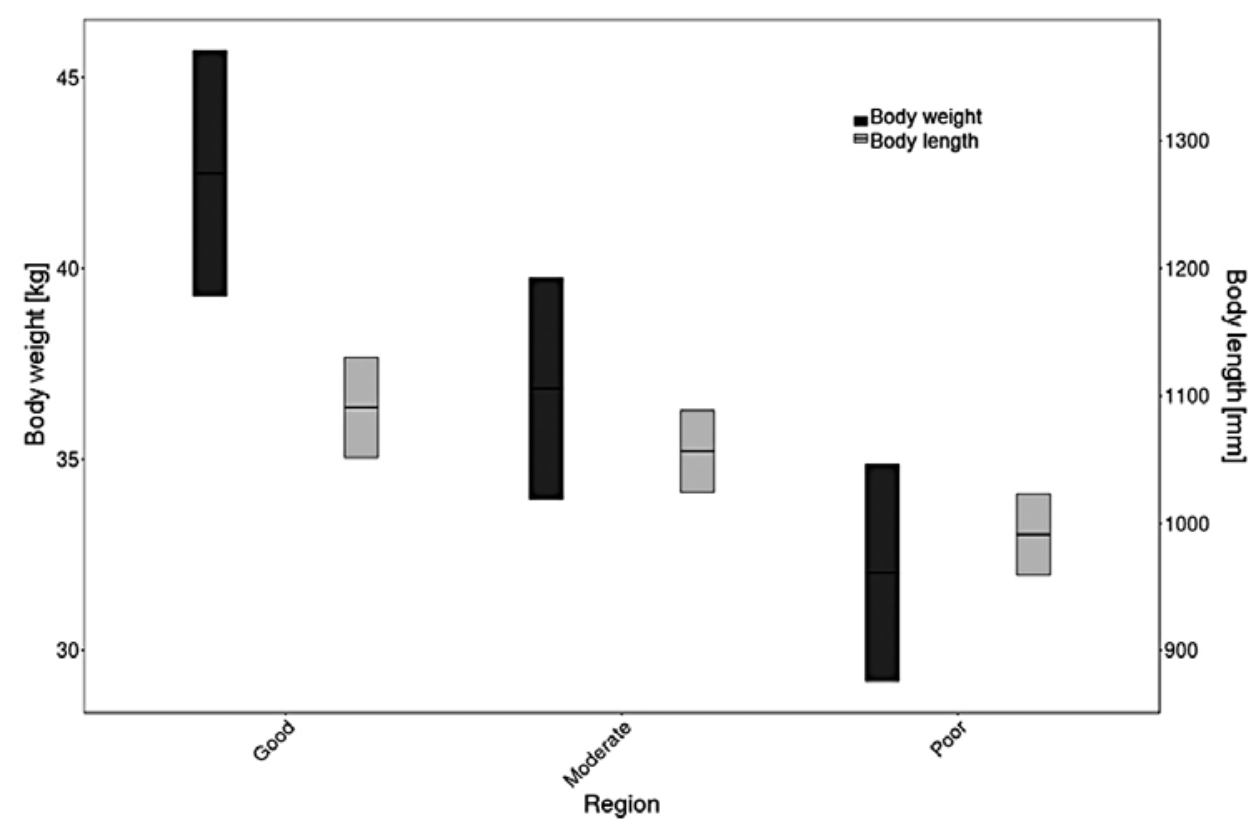

Fig. 3. Body weight and length of piglets 5-11 months old depending on the quality of the environment

The environment significantly affected the GSI values of piglets (Fig. 4). In GOOD environments, despite higher body weight, testes were relatively bigger than in other environments (GSI in GOOD environment: $0.13 \%$; MODERATE environment: $0.10 \%$, and POOR environment: $0.05 \%$ ). The differences in GSI between locations were caused by testicular weight $(\mathrm{r}=0.93 ; P<0.001)$ to a higher extent than by body weight $(\mathrm{r}=0.81$; $P<0.001$ ). Boars living in high quality conditions grow and sexually mature faster, so their testes were significantly more developed. The most notable connection between the acquired data about testes and body parameters was observed between body weight and testicular length $(\mathrm{r}=0.67 ; P<0.001)$.

Sperm was not observed in piglets younger than 5 months. In piglets aged 6-7 months, sperm was observed in 63\% of piglets living in GOOD and MODERATE environments, but only in $17 \%$ of piglets from a POOR environment. Every piglet aged 8 months and living in GOOD or MODERATE conditions had sperm in its testes, while piglets from POOR conditions had sperm only in $83 \%$ of cases (100\% from 9 months on). Every piglet weighing $29 \mathrm{~kg}$ and more already had sperm in its testes. This corresponds to $23 \mathrm{~g}$ in gonad 


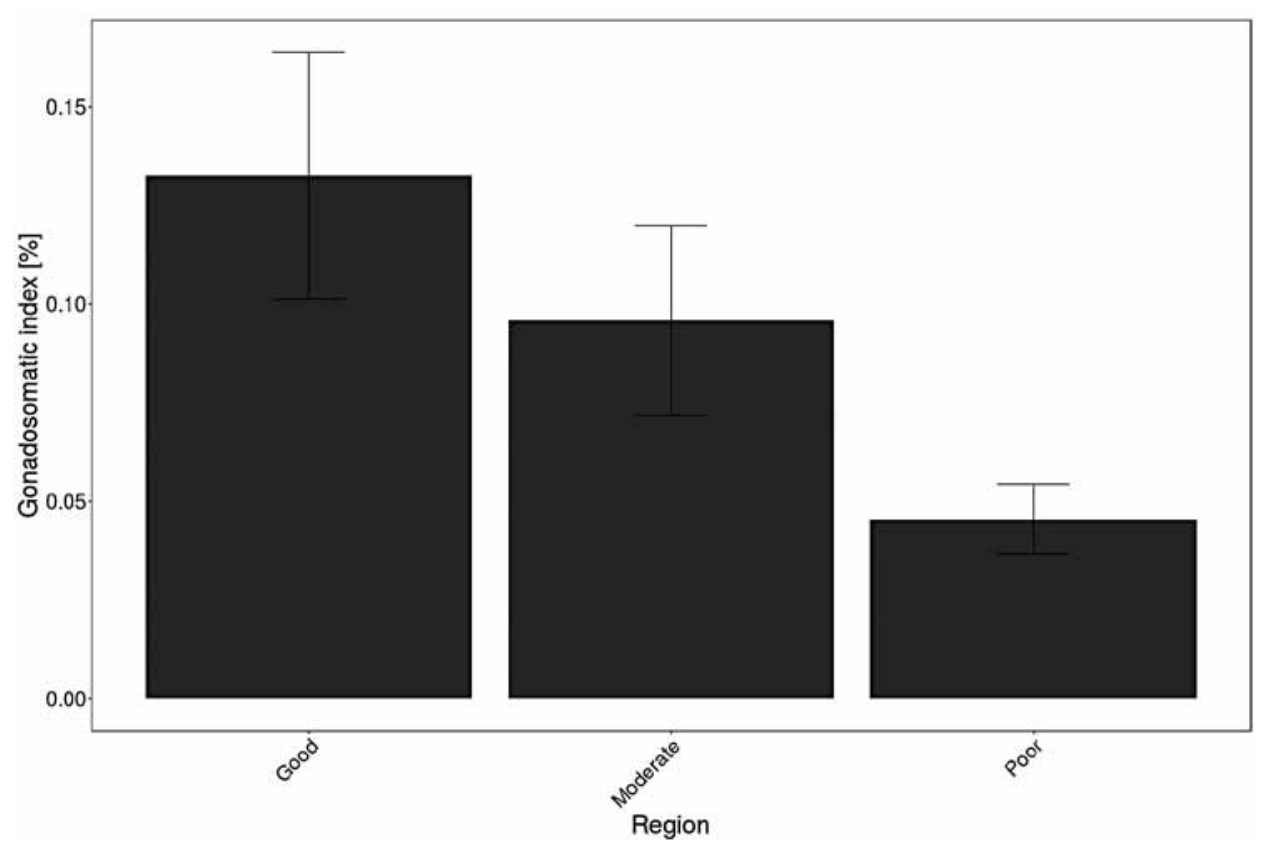

Fig. 4. Gonadosomatic index of piglets 5-11 months old depending on the quality of the environment

weight $(\mathrm{GSI}=0.08 \%)$; sperm was individually observed starting at $8 \mathrm{~g}$ (the mean weight of one testicle was $4 \mathrm{~g}$, Table 4 ).

The final selected model of probability of sperm occurrence with the highest accuracy $(92 \%)$ had the following formula:

Sperm_presence (body_weight, testicle_length, testicle_weight) $=0.164$ body_weight +0.013 testicle length $+\overline{0} .041$ testicle weight -18.406

In addition, it can be concluded that the presence of sperm is more dependent on body weight than on age (Fig. 5).

\section{Discussion}

This study complements findings from the field of wild boar reproductive biology. While females have been studied extensively, there are few studies focusing on males. From an ecological point of view, its reproductive strategy is somewhere between $r$ - and K-selection; the boar is able to reach high population density in a very short period of time (Frauendorf et al. 2016). This is determined by the litter size, positively influenced by high precipitation and temperatures in the summer, as well as higher oak mast yield, and also, indirectly, by the climate, which affects the weight of the mother through nutrition.

The weight of the mother and the entire population is also supported by agricultural policy oriented towards extensive production of energy crops (maize, rapeseed or grain) (Cahill et al. 2003; Herrero et al. 2006) and supplementary feeding from hunters (Oja et al. 2015). This way, the boar never feels nutritionally deprived, not even out of growing seasons (Oja et al. 2014). Unless it is burdened with major health problems or other types of stress, the increase in average weight and body frame size can continue undisturbed, depending on environmental conditions (especially energy-rich food sources). It differs 


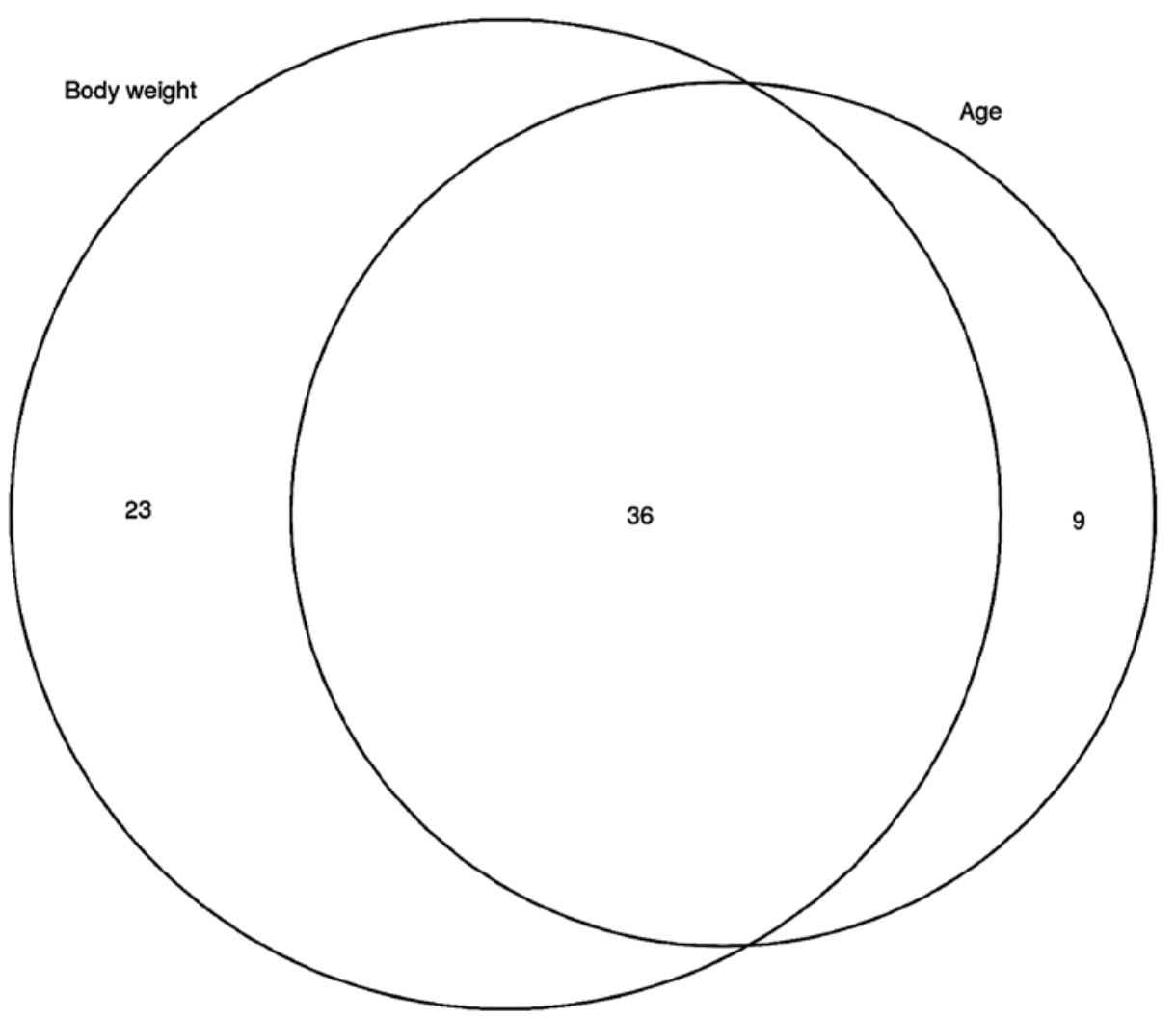

Fig. 5. Percentage of variability in sperm presence explained by body weight, age and both

in males and females. Pedone et al. (1991) and Gallo Orsi et al. (1995) discussed the weight differentiation between sexes under 12 months of age, when males invest all their energy into growth, while females must also invest it in reproduction, causing them to grow slower. Ježek et al. (2011) also state that the effect of location as a factor affecting morphometric parameters is very important in boars in their first year of life. This factor also proved to be important in the present study focused on males. In a high-quality environment where boars were not stressed by hunts over the course of the year and had enough rest, shelter and nutrition, they reached larger body sizes and higher weights sooner than boars in an environment with fewer resources (especially with limited availability of energy-rich nutrition) and generally more stressful environments.

An important role is also played by wild boar diseases, which may affect the growth and overall form of piglets in particular. As a result of their organisms coping with infection, they may fall behind in growth (Patra et al. 2013). García-González et al. (2013), for example, found a $41.01 \%$ prevalence of metastrongylosis in boars caught in Southwestern Spain. However, evaluating the state of their health was not the aim of this study. In general, Pedone et al. (1995) indicate that a boar acquires $50 \%$ of its adult weight within the first 12 months and $70 \%$ of its adult weight within the first 22 months. These findings are also confirmed by the results of this study. 
The mean weights of the three main age groups of this study showed similar values to the ones found by Sprem et al. (2011), although they were higher than values found by Herrero and Fernandez de Luco (2003) and Delgado et al. (2008). Using body parameters, it is possible to compare body lengths of the examined boars according to research by Ježek et al. (2011), who evaluated boars caught in several different areas of the Czech Republic using similar age groups, and found values very close to the values observed in our study. They were also very close to the values observed in other parts of Europe such as Germany (Gethöffer et al. 2007) and Switzerland (Hebeisen 2007).

The sampling areas (hunting grounds) for this study were selected in order to match the pre-defined types of environment considering the wider surroundings. Areas with ambiguous environmental characteristics were excluded from the study in advance, according to the study by Truvé and Lemel (2003). They found that young males begin to disperse at the age from 10 to 16 months within a maximal distance of $16.6 \mathrm{~km}$ from their natal sites. As the average size of the home range is about 800 ha (Keuling et al. 2018), hunting grounds with a minimum area of 1000 ha had been selected in order to make sure that the hunted wild boars were present in the areas also during the growing season. This confirmed the assumption that wild boars were born, lived and were hunted in the same type of environment. This study assessed the dimensions of gonads and the occurrence of sperm in boars killed during common hunts. These usually take place during a time referred to as the main reproductive period of the wild boar (November-January). An effect of the shortening light phase of the day on physiological changes stimulating the reproductive function of the testes was proven not only in females, but also in males (Smital 2009). Most studies were aimed at domestic pigs kept on farms, but Kozdrowski and Dubiel (2004) state that the ejaculates of domestic pigs and wild boars are not significantly different. Pig ejaculate tested in autumn and in early winter showed a higher concentration of sperm and their total volume, as well as a higher proportion of motile sperm (Mauget and Boissin 1987; Marchev et al. 2003; Kozdrowski and Dubiel 2004; Sancho et al. 2004; Smital 2009). Schopper et al. (1984) showed the highest steroid hormone production values in autumn and early winter. Mauget and Boissin (1987) point out that testicular weight and volume, as well as testosterone concentrations in the blood, are at their highest in winter. Chinchilla-Vargas et al. (2018), on the other hand, point out changes in reproductive characteristics in domestic pigs caused by climatic phenomena and phases of the moon.

Thus, there is a correspondence between the reproductive periods of females and sperm production in males, with the female reproductive activity being strongly seasonal. The ovarian cycles of females can be interrupted due to food shortages in winter, but also due to, e.g. high summer temperatures (Thibault et al. 1966; Peltoniemi et al. 1999; Tummaruk et al. 2000). It is a time when follicles do not mature in the ovaries of the wild sow and fertilizable eggs are not released. According to the study conducted by Schopper et al. (1984), the libidos of domestic pigs were disrupted from mid-July to mid-September; they refused to jump on the figurine used to collect sperm for the artificial insemination of domestic sows. Kozdrowski and Dubiel (2004) discovered an absence of copulation as early as in May. The maximum productivity of the testes coincides with the main reproductive period of the females (Smital 2009).

As mentioned above, many authors considered the weight of young females to be a more important factor influencing the onset of sexual maturity in piglets than the actual physiological age of the animal. Through analyses of the occurrence of sperm in testes of young adult males, this has also been confirmed in this study. Changes in dimensions of the testes occurring as a part of their physiological development are caused by cytological and structural changes to the testes within the relevant age groups (Ogwu et al. 2009). This suggests a close relationship between testicle sizes for each age group and the spermatogenic and endocrinal activity in the testes. In the first few months, they initially exhibit slow 
growth as a result of the cell proliferation period (Thomas and Raja 1980). As puberty approaches, the growth accelerates due to the expansion of lumen and thickening of the walls of seminiferous tubules. After reaching their sexual maturity, the growth slightly slows down due to an increase in the volume of connective tissue (Schinckel et al. 1983; Assis Neto et al. 2003; Murta et al. 2013). This accelerated growth in puberty and the post-pubertal period is related to an increase in the volume of Sertoli cells and the mitotic division of reproductive cells in seminiferous tubules, which leads to the formation of primary spermatocyte out of spermatogonia. Environment quality has been proven to cause an earlier onset of sexual maturity in piglets. This is due to the piglets achieving threshold weight faster in quality environments, which is also related to the weight (and volume) of their gonads (Ogwu et al. 2009).

The ratio of body and testicular weight was initially more or less constant; this was followed by rapid growth starting at month 8 and peaking during month 10, which could be caused by impending puberty, as described by Murta et al. (2013) and Ferreira et al. (2004). After that, the growth gradually slowed and reached constant values again. The gonadosomatic index growth is represented by a sigmoid curve. The acquired GSI values corresponded to the findings of similar studies of boars of comparable ages and in comparable seasons. Almeida et al. (2006) state that GSI fluctuates during the rutting season (November/January). In males of the Brazilian population of Sus scrofa scrofa aged around 10 months, these authors found a GSI of $0.3 \%$ (which corresponds to the present mean value acquired from young adults). The high correlations found between gonad parameters and the weight/age of the males in this study have already been described in both domestic pigs (Thomas and Raja 1980; França and Cardoso 1998; França et al. 2005) and wild boars (Sprem et al. 2011). Domestic pigs exhibit higher GSI values compared to wild boars. Almeida et al. (2006) think this is caused by the selective reproductive process on farms, which leads to an increase of the effectiveness of Sertoli cells, or an increase in total testicular weight.

The weight threshold for sperm occurrence in the testes was $29 \mathrm{~kg}$ of live weight, which corresponds to 6 months of age. This observation does not match the findings of Mauget and Boissin (1987), who observed the presence of spermatozoa in the epididymides of boars from midwestern France, starting at 10 months of age, with a mean testicular weight of 53 g. However, our observation does correspond to the weight threshold for sperm occurrence (30-35 kg) observed by Mauget and Boissin (1987). The correlation coefficient between testicular and body weights was very high in comparison to other studies (Mauget and Boissin 1987: $r=0.67$; Schinckel et al. 1983: $r=0.51-0.70 ;$ Murta et al. 2013: $r=0.90$ ).

This study has proven that environmental conditions are a significant factor affecting the physical development of male wild boars, more specifically the growth rate of their body frames and the onset of sexual maturity. In an environment with sufficient food, rest, and shelter, boars grow faster and enter puberty at an earlier age. In environments with hunters and fewer resources, the boars are exposed to long-term stress, which leads to slower body and testicular growth, as well as the production of sperm at a later age (approx. 2-3 months later).

\section{Acknowledgements}

This study was supported by the Specific University Research Fund of the FFWT Mendel University in Brno, Grant No. LDF_PSV_2016013. Spaces for laboratory analyses were provided by the Department of Morphology, Physiology and Animal Genetics, and Department of Animal Breeding, Faculty of AgriSciences, Mendel University in Brno. We also thank Zuzana Rečková for help with laboratory analyses and Ken Urquhart for language revision.

\section{References}

Almeida FFL, Leal MC, França LR 2006: Testis morphometry, duration of spermatogenesis, and spermatogenic efficiency in the wild boar (Sus scrofa scrofa). Biol Reprod 75: 792-799 
Apollonio M, Andersen R, Putman R (Eds) 2010: European ungulates and their management in the $21^{\text {st }}$ century. Cambridge University Press, Cambridge, United Kingdom

Assis Neto AC, Melo MIV, Carvalho MAM, Miglino MA, de Oliveira MF, Ambrósio CE, Medeiros de Sousa Silva SM, Hernandez Blasquez FX, de Carvalho Papa P, Kfoury JR, Jr. 2003: Quantificação de células dos túbulos seminíferos e rendimento da espermatogênese em cutias (Dasyprocta aguti) criadas em cativeiros (Histologic quantification of the seminiferous tubules cells and spermatogenesis yield in Agoutis (Dasyprocta aguti) rised in captivity). Braz J Vet Res Anim Sci 40: 175-179

Barber BJ, Blake NJ 1991: Reproductive physiology. In: Shunway S (Ed.), Scallops: Biology, Ecology and Aquaculture. Elsevier, Amsterdam, pp. 377-409

Bekaert KM, Aluwé M, Millet S, Goethals K, Nijs G, Isebaert S, De Brabander DL, Verheyden K, De Brabander HF, Vanhaecke L, Tuyttens FA 2012: Predicting the likelihood of developing boar taint: Early physical indicators in entire male pigs. Meat Sci 92: 382-385

Boitani L, Mattei L 1992: Ageing wild boar (Sus scrofa L.) by tooth eruption. In: Spitz F, Janeau G, Gonzalez G, Aulagnier S (Eds), Ongulés/Ungulates. SFEPM-IRGM, Paris-Toulouse, pp. 399-402

Briedermann L 1965: Les composantes de l'alimentation du Sanglier en Europe Centrale. Rapports di VIIème de l'Union des Biologistes du Gibier. Belgrade Ljubljane, pp. 207-213

Cahill S, Llimona F, Gràcia J 2003: Spacing and nocturnal activity of wild boar (Sus scrofa) in a Mediterranean metropolitan park. Wildl Biol 9: 3-13

Carpentier A, Chaussade H, Rigaud E, Rodriguez J, Berthault C, Boue F, Tognon M, Touzé A, Garcia-Bonnet N, Choutet P, Coursaget P 2012: High hepatitis E virus seroprevalence in forestry workers and in wild boars in France. J Clin Microbiol 50: 2888-2893

Chinchilla-Vargas J, Kerns K, Rothschild MF 2018: Lunar and climatic effects on boar ejaculate traits. Anim Reprod Sci 193: 117-125

Delgado R, Fernández-Llario P, Azevedo M, Beja-Pereirac A, Santos P 2008: Paternity assessment in free-ranging wild boar (Sus scrofa) - Are littermates full-sibs? Mammal Biol 73: 169-176

Delgado-Acevedo J, Zamorano A, DeYoung RW, Campbell TA, Hewitt DG 2011: Promiscuous mating in feral pigs (Sus scrofa) from Texas, USA. Wildl Res 37: 539-546

Fernández-Llario P, Carranza J, Mateos-Quesada P 1999: Sex allocation in a polygynous mammal with large litters: the wild boar. Anim Behav 58: 1079-1108

Ferreira ACS, Guimarães DAA, Luz-Ramos RS, Souza PC, Batista CR, Ohashi OM 2004: Reproductive developmental of male agouti (Dasyprocta sp.) raised in captivity determined by quantitative analysis of spermatogenic cells. Rev Bras Reprod Anim 28: 196-201

França LR, Cardoso FM 1998: Duration of spermatogenesis and sperm transit time through the epididymis in the Piau boar. Tissue Cell 30: 573-582

França LR, Avelar GF, Almeida FF 2005: Spermatogenesis and sperm transit through the epididymis in mammals with emphasis on pigs. Theriogenology 63: 300-318

Frauendorf M, Gethöffer F, Siebert U, Keuling O 2016: The influence of environmental and physiological factors on the litter size of wild boar (Sus scrofa) in an agriculture dominated area in Germany. Sci Total Environ 541: 877-882

Friedman J, Hastie T, Tibshirani R 2010: Regularization paths for generalized linear models via coordinate descent. J Stat Soft 33: 1-22

García-González ÁM, Pérez-Martín JE, Gamito-Santos JA, Calero-Bernal R, Alcaide Alonso M, Frontera Carrión EM 2013: Epidemiologic study of lung parasites (Metastrongylus spp.) in wild boar (Sus scrofa) in Southwestern Spain. J Wildl Dis 49: 157-162

Gallo Orsi U, Macchi E, Perrone A, Durio P 1995: Biometric data and growth rates of a wild boar population living in the Italian Alps. IBEX JME 3: 60-63

Gethöffer F, Sodeikat G, Pohlmayer K 2007: Reproductive parameters of wild boar (Sus scrofa) in three different parts of Germany. Eur J Wildl Res 53: 287-297

Hebeisen C 2007: Population size, density and dynamics, and social organization of wild boar (Sus scrofa) in the Basin of Geneva. [PhD. Thesis.] University of Neuchâtel, Geneva

Herrero J, Fernández de Luco D 2003: Wild boars (Sus scrofa L.) in Uruguay: Scavengers or predators? Mammalia 67: 485-491

Herrero J, García-Serrano A, Couto S, Ortuño VM 2006: Diet of wild boar Sus scrofa L. and crop damage in an intensive agroecosystem. Eur J Wildl Res 52: 245-250

Ježek M, Štípek K, Kušta T, Červený J 2011: Reproductive and morphometric characteristics of wild boar (Sus scrofa) in the Czech Republic. J For Sci 57: 285-292

Keuling O, Podgórski T, Monaco A, Melletti M 2018: Eurasian Wild Boar Sus scrofa (Linnaeus, 1758). In: Melleti M, Meijaard E (Eds): Ecology, Conservation and Management of Wild Pigs and Pecaries. Cambridge University Press, Cambridge, pp. 202-233

Kozdrowski R, Dubiel A 2004: The effect of season on the properties of wild boar (Sus scrofa L.) semen. Theriogenology 80: 281-289

Marchev Y, Apostolov A, Szostak B 2003: Season and age effect on sperm quality and quantity in boars from the Danube White breed. Bulg J Agric Sci 9: 703-706 
Massei G, Genov PV 2004: The environmental impact of wild boar. Galemys 16: 135-145

Massei G, Kindberg J, Licoppe A, Gačić D, Šprem N, Kamler J, Baubet E, Hohmann U, Monaco A, Ozolinš J, Cellina S, Podgórski T, Fonseca C, Markov N, Pokorny B, Rosell C, Náhlik A 2015: Wild boar populations up, numbers of hunters down? A review of trends and implications for Europe. Pest Manag Sci 71: 492-500

Matschke GH 1967: Ageing European wild hogs by dentition. J Wildl Manag 31: 109-113

Mauget R, Boissin J 1987: Seasonal changes in testis weight and testosterone concentration in the European wild boar (Sus scrofa L.). Anim Reprod Sci 13: 67-74

Mauget R 1972: Observations sur la reproduction du sanglier (Sus scrofa L.) a l'état sauvage. Ann Biol Anim Bioch Biophys 12: 195-202

Murta DVF, Costa DS, Santos MD, Faria FJC, Paula TAR 2013: Corporal and testicular biometry in wild boar from birth to 12 months of age. Rev Ceres 60: 1-6

Ogwu SOC, Onyimonyi AE, Foleng H 2009: Testicular development and relationship between body weight, testis size and sperm output in tropical boars. Afr J Biotechnol 8: 1165-1169

Oja R, Kaasik A, Valdmann H 2014: Winter severity or supplementary feeding - which matters more for wild boar? Acta Theriol 59: 553-559

Oja R, Zilmer K, Valdmann H 2015: Spatiotemporal effects of supplementary feeding of wild boar (Sus scrofa) on artificial ground nest depredation. PLoS ONE 10: e0135254

Orłowska L, Rembacz W, Florek C 2013: Carcass weight, condition and reproduction of wild boar harvested in north-western Poland. Pest Manag Sci 3: 367-370

Patra G, Prasad H, Lalsiamthara J, Kataria JL, Malsawmkima D, Lalrinkima H 2013: Lungworm infestation in piglets in different parts of Mizoram, India. J Parasitol 8: 37-44

Pedone P, Mattioli L, Mattioli S 1995: Body size and growth patterns in wild boars of Tuscany, central Italy. IBEX JME 3: 66-68

Pedone P, Mattioli L, Mattioli S, Simeoni N, Lovari C, Mazzarone V 1991: Body growth and fertility in wild boars of Tuscany, Central Italy. In: Csanyi S, Ernhaft J (Eds): Transactions of the XXth IUGB Congress Part II. University of Agricultural Sciences, Gödöllö, pp. 604-609

Peltoniemi OAT, Love RJ, Heinonen M, Tuovinen V 1999: Seasonal and management effects on fertility of the sow: A descriptive study. Anim Reprod Sci 55: 47-61

Pérez-González J, Costa V, Santos P, Slate J, Carranza J, Fernández-Llario P, Zsolnai A, Monteiro NM, Anton I, Buzgó J, Varga G, Beja-Pereira A 2014: Males and females contribute unequally to offspring genetic diversity in the polygynandrous mating system of wild boar. PLoS ONE 9: e115394

R Development Core Team 2008: R: A language and environment for statistical computing. R Foundation for Statistical Computing, Vienna, Austria

Ritz C, Baty F, Streibig JC, Gerhard D 2015: Dose-response analysis using R. PLoS ONE 10: e0146021

Sánchez-Vizcaíno JM, Mur L, Martínez-López B 2013: African swine fever (ASF): five years around Europe. Vet Microbiol 165: 45-50

Sancho S, Pinart E, Briz M, Garcia-Gil N 2004: Semen quality of postpubertal boars during increasing and decreasing natural photoperiods. Theriogenology 62: 1271-1282

Schinckel A, Johnson RK, Pumfrey RA, Zimmerman DR 1983: Testicular growth in boars of different genetic lines and its relationship to reproductive-performance. J Anim Sci 56: 1065-1076

Schopper D, Gaus J, Claus R, Bader H 1984: Seasonal changes of steroid concentrations in seminal plasma of a European wild boar. Acta Endocrinol (Copenhagen) 107: 425-427

Smital J 2009: Effects influencing boar semen. Anim Reprod Sci 110: 335-346

Sprem N, Piria M, Florijančić T, Antunović B 2011: Morphometrical analysis of reproduction traits for the wild boar (Sus scrofa L.) in Croatia. Agric Conspec Sci 76: 263-265

Thibault C, Courot M, Martinet L, Mauleon P, du Mesnil du Buisson F, Ortavant R, Pelletier J, Signoret JP 1966: Regulation of breeding season and oestrus cycles by light and external stimuli in some mammals. J Anim Sci 25: $119-139$

Thomas UP, Raja CKSV 1980: Postnatal development of testis and epididymis of Large White Yorkshire boars. J Vet Sci 2: 277-286

Truvé J, Lemel J 2003: Timing and distance of natal dispersal for wild boar Sus scrofa in Sweden. Wildl Biol 9(suppl): $51-57$

Tummaruk P, Lundeheim N, Einarsson S, Dalin AM 2000: Reproductive performance of purebred Swedish Landrace and Swedish Yorkshire sows I. Seasonal variation and parity influence. Acta Agric Scand 50: 205-216

Věžník Z, Švecová D, Zajícová A, Přinosilová P 2004: Repetitorium: spermatology and andrology and sperm analysis methodology. Veterinary Research Institute, Brno 